\title{
Assessment of Pathogen Inactivation under Sub-composting Temperature in Lab-scale Compost Piles
}

\author{
Venkata Vaddella ${ }^{1}$, Pramod Pandey ${ }^{1,2}$, Wenlong Cao ${ }^{1}$, Sagor Biswas ${ }^{1}$, Collen Chiu ${ }^{1}$, Yawen Zheng ${ }^{1}$, Tong Wu ${ }^{1}$, \\ Nada Ghanem ${ }^{3}$ \& Fatih Buyuksonmez ${ }^{4}$ \\ ${ }^{1}$ Department of Population Health and Reproduction, School of Veterinary Medicine, University of California \\ Davis, California, USA \\ ${ }^{2}$ Division of Agriculture and Natural Resources, University of California Cooperative Extension, California, \\ USA \\ ${ }^{3}$ Faculty of Agricultural and Food Sciences at the American University of Beirut, Beirut, Lebanon \\ ${ }^{4}$ Department of Civil, Construction and Environmental Engineering, San Diego State University, California, \\ USA \\ Correspondence: Pramod K Pandey, Department of Population Health and Reproduction, School of Veterinary \\ Medicine, University of California, Davis, CA 95616, USA. Tel: 530-219-6286. E-mail: pkpandey@ucdavis.edu
}

Received: February 18, 2018

Accepted: March 9, 2018 Online Published: April 3, 2018

doi:10.5539/jfr.v7n3p64

URL: https://doi.org/10.5539/jfr.v7n3p64

\begin{abstract}
This study was conducted to assess the temperature profile and corresponding pathogen inactivation in lab-scale compost piles. The variation in temperature at different locations of piles and $E$. coli concentrations was evaluated. The experiment design included plastic containers of different height filled with organic feedstock. Cotton balls soaked with pathogens $(E$. coli and $E$. coli $\mathrm{O} 157: \mathrm{H} 7)$ were placed inside the feedstocks at various depths. Subsequently, change in pathogen concentrations, feedstock characteristics, and temperature was monitored over time. Observations showed fluctuation in temperature of piles. The peak temperature $\left(>50{ }^{\circ} \mathrm{C}\right)$ was reached after two weeks of expertiment. The concentrations of E.coli and E. coli O157: H7 at different depths varied among piles during the 35 days of experiments. The reductions in E. coli concentrations ranged 14 orders of magnitude. In certain piles, reduction in E. coli concentrations was followed by increased in E. coli levels indicating the possibility of perturbation of bacteria in the feedstock potentially at low temperature. We anticipate these preliminary results will provide additional insights on pathogen inactivation in compost system. The approach used here can be implemented at field-scale compost piles for assessing pathogen inactivation during compost process under field conditions.
\end{abstract}

Keywords: compost, pathogens, temperature, recycling

\section{Introduction}

Renewed attention on various recycling methods including composting and anaerobic digestion processes requires improved understanding of various aspects of these processes. One of the main concerns is uncertainty in pathogen inactivation during composting. While anaerobic digestion process is often used for producing bio-methane (renewable energy) from liquid and semi-solid wastes (such as flushed dairy manure, swine manure, and poultry manure), composting process is used for converting solid organic waste into organic fertilizers. Composting process is known to reduce pathogen levels in compost (end-product) (Cole, 2015; Erickson, Liao, Ma, Jiang \& Doyle, 2014; Zhou et al., 2015) because it increases the temperature of feedstock of piles, which is lethal to many pathogens. The reductions in concentrations of many zoonotic pathogens including Mycobacterium avium subs. Paratuberculosis, E. coli, Salmonella spp., and Listeria monocytogenes during composting process are published (Grewal, Rajeev, Sreevatsan, \& Michel, 2006; Turner, 2002).

In general, composting process are used for treating organic waste including dairy, swine and chicken manure, green waste, food waste, and carcasses of poultry and livestock animals (Blake \& Donald, 1992; Stanford, Reuter, Gilroyed, \& McAllister, 2015; Yang, Hou, Zhai, \& Zhang, 2015). In addition to producing organic fertilizer, composting of pig manure is reported to produce maggots, which is used as a feed supplement (Zhu et al., 2012). Composting process is also used for converting dairy and poultry manure into organic fertilizers. 
Further, the composting process is used for degrading carcasses of poultry and livestock, and reducing the risk of pathogens including avian influenza dissemination during emergency situations (Pandey, Cao, Wang \& Vaddella, 2016; Vaddella et al., 2016).

The inactivation of pathogens in the composting process largely depends on the compost temperature (Wichuk \& McCartney, 2007). Previous studies have reported that temperature greater than $55-60{ }^{\circ} \mathrm{C}$ in compost piles accelerates the pathogen inactivation, whereas temperature lower than $55-60{ }^{\circ} \mathrm{C}$ prolongs the pathogen survival. As an example, Toth, Aceto, Rankin, \& Dou (2011) reported that Salmonella Newport was eliminated in static compost piles in less than $18 \mathrm{hrs}$. The temperature of the composting pile was greater than $64{ }^{\circ} \mathrm{C}$. However, when the temperature of the pile was $38^{\circ} \mathrm{C}$, Salmonella survival was extended for greater than 2.5 days in bio-solid compost (Ahmed \& Sorensen, 1995). Another study by Shepherd, Liang, Jiang, Doyle \& Ercikson (2007) reported that $E$. coli survived 14 days in dairy manure pile during composting [temperature of the pile was $50{ }^{\circ} \mathrm{C}$ ]. The survival of $E$. coli in dairy cow manure was extended to 6 weeks when the composting pile temperature was kept constant at $30^{\circ} \mathrm{C}$ (Erickson, Smith, Jiang, Flitcroft, \& Doyle, 2015).

Similarly, Jiang, Morgan, \& Doyle (2003) showed that E. coli O157:H7 survived for 36 days during composting in a bioreactor at a temperature of $21^{\circ} \mathrm{C}$. The pathogen inactivation was faster at $50{ }^{\circ} \mathrm{C}$. At this temperature, the pathogen level reached to an undetectable level after 7 to 14 days. Other study tested the use of composting for reducing avian influenza in poultry carcasses and reported that composting pile [with the temperature of 50 to 60 $\left.{ }^{\circ} \mathrm{C}\right]$ reduced viruses in poultry carcasses to an undetectable level in 10 days (Senne, Panigrahy, \& Morgan, 1994).

In addition to feedstock, Fernandes, Zhan, Patni, \& Jui (1994) reported that temperature in compost pile was also influenced by pile depths, weather, and mixing. While composting of poultry manure slurry with peat moss and chopped stray, the authors found that the average peak temperature at the bottom section (near the surface of the pile) was $56-57^{\circ} \mathrm{C}$, the middle section ranged from $61-72^{\circ} \mathrm{C}$, and at the top section the temperature range was $59-72{ }^{\circ} \mathrm{C}$ in $1 \mathrm{~m}$ high compost piles.

In addition to the location within the pile, the size of the piles also influences temperature profile of the compost. For example, Sartaj, Fernandes, \& Patni (1997) reported that when the average pile height was $1.2 \mathrm{~m}$, the compost pile reached to a temperature range of $54-56{ }^{\circ} \mathrm{C}$. Luo et al. (2008) found that the temperature at the bottom of the pile ( $75 \mathrm{~cm}$ from the surface) was higher than the top surface $(28 \mathrm{~cm}$ from the outer surface) when composting the sewage sludge and the temperature might vary $10{ }^{\circ} \mathrm{C}$ between the surfaces. Due to the strong relationship between temperature and pathogen survival (Biswas, Pandey, \& Farver, 2016; Pandey, Biswas, Vaddella, \& Soupir, 2015), improvement in understanding of how the location within the pile and pile depths influences compost temperature is necessary. The current understanding of how the depths of the compost pile influences temperature profiles and corresponding pathogen inactivation is weak. The goal of this research is to improve the understanding of changes in temperature and pathogen levels with respect to the pile depths. The objectives were: 1) to evaluate the temperature profiles of compost corresponding to the pile depths and heights; and 2) to assess the impacts of pile depth, sizes, and composting time on the inactivation of compost pathogens.

\section{Material and Methods}

\subsection{Compost Pile Preparation and E. coli O157: H7 Inoculation}

The experiment was carried-out in a barn located at the Teaching and Research Animal Care Services (TRACS) facility of the University of California- Davis (UC Davis). A half compost pile was simulated using total 14 plastic bins ( 19 L capacity each; Model: 05GLHD2) stacked on each other to make four columns depicted in Figure 1a. The bin dimension was $25 \mathrm{~cm} \times 35 \mathrm{~cm}$ (diameter $\times$ height). The compost columns (piles) were formed by stacking 5, 4, 3, and 2 bins in column 1,2,3, and 4, respectively (Figure 1a). The piles of various heights were placed outdoor adjacent to each other on the ground $15 \mathrm{~cm}$ apart in the ambient temperature. Holes were drilled at the bottom surface of each bin to facilitate air and heat transfer among the bins. A separate $5 \mathrm{~cm}$ (diameter) hole (i.e., passage) was drilled on the outer surface of the bin at $15 \mathrm{~cm}$ height from the base of the bin to facilitate sampling.

To prepare the feedstock, we mixed wood chips, horse manure, and straw using a bio-mixer (BioMixer-200 L, Daega Powder Systems Co., Ltd). The horse manure was obtained from UC Davis Equine Center, and hay was obtained from UC Davis Hay Barn. The feedstock in each bin consisted of approximately $3 \mathrm{~kg}$ of wood chips (Scotts Earthgro, Model: 647185) used as a bulking agent (50\%), $2 \mathrm{~kg}$ of horse manure (33\%), and $1 \mathrm{~kg}$ of hay $(17 \%)$. Each bin received $6 \mathrm{~kg}$ of feedstock and stacked on each other to form columns as shown in the Figure 1. The bins were filled with the prepared feedstock up to the height of the drilled hole $(15 \mathrm{~cm}$ height $)$ and then 12 cotton balls (approximately $2.5 \mathrm{~cm}$ diameter) saturated in media containing E. coli O157: $\mathrm{H} 7$ were placed in the middle of each bin with the feedstock. The additional feedstock was placed on the top of the cotton balls to fill 
each of bins. The total depth of feedstock in each bin was $20 \mathrm{~cm}$.

(a)

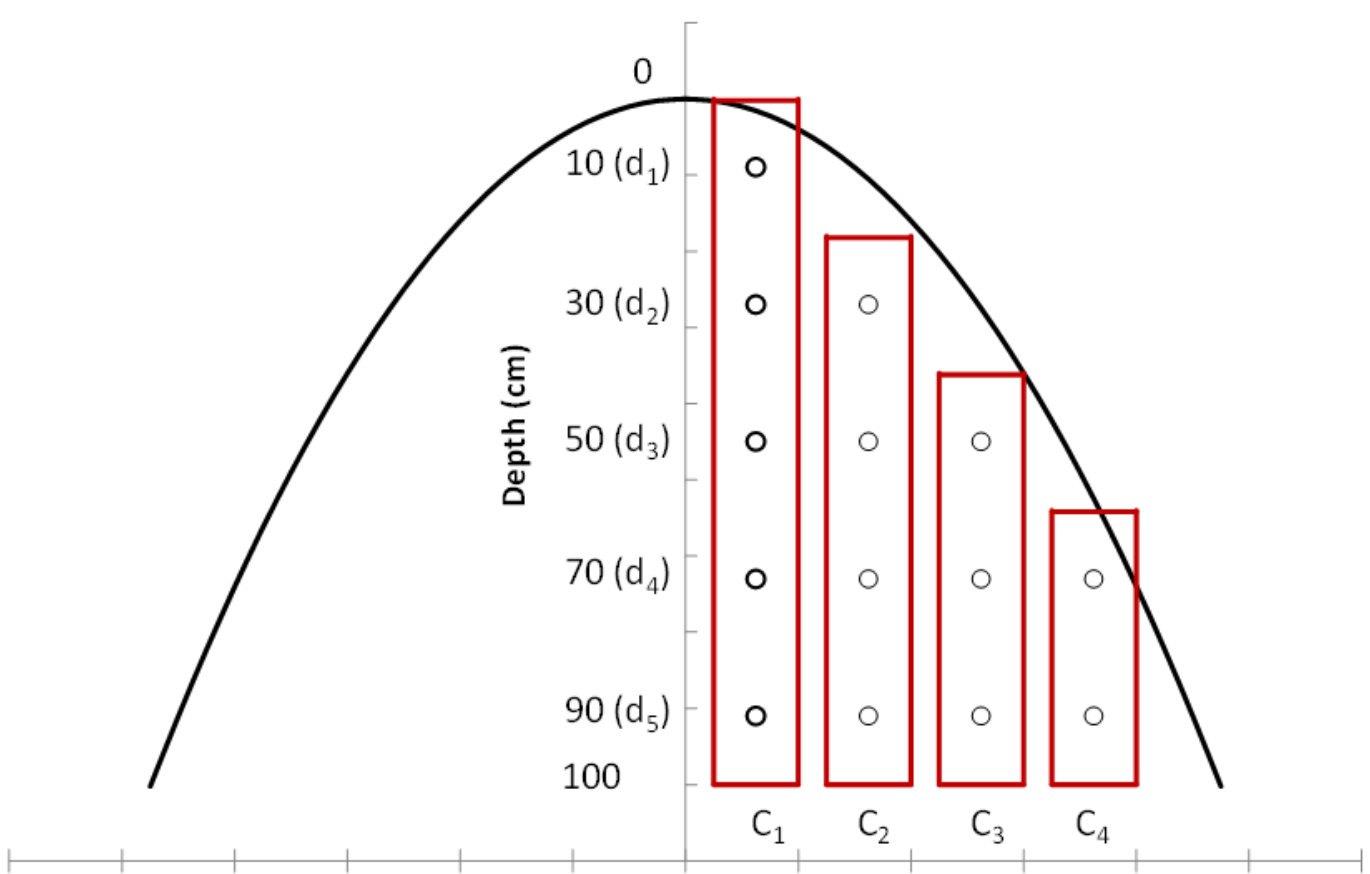

Width $(\mathrm{cm})$

(b)

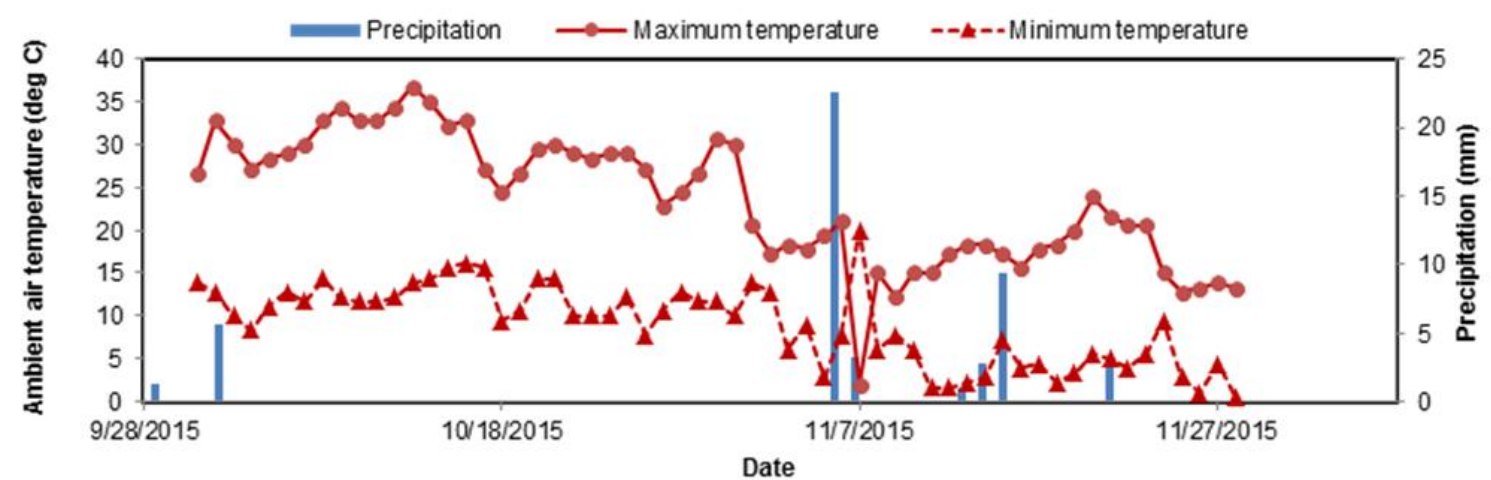

Figure 1. Sketch of Experiment setup: a) sketch of compost bins; b) ambient temperature and precipitation

\subsection{Inoculation and Enumeration of E. coli}

To prepare inoculum of E. coli O157: H7, we used Luria-Bertani (LB) broth (Difco LB Broth Miller; Becton, Dickinson and Company, Sparks, MD, USA) for growing pure strains of E. coli O157: H7 (ATCC\# 35150). Enriched media was used for cotton balls saturation; these cotton balls soaked with $E$. coli were placed inside the piles. The culture was grown in an incubator shaker at $100 \mathrm{rpm}$ and $37{ }^{\circ} \mathrm{C}$ for $24 \mathrm{~h}$ (bench top MaxQ 4000, Thermo Scientific, Ohio, USA). A negative control was used to ensure the quality control. The pure culture was plated in selective media to confirm and enumerate E. coli O157: H7 concentrations, which served as an initial concentration in the inoculum.

Pathogen enumeration in pure culture, the cotton media, and in the feedstock was carried out following the Bacteriological Analytical Manual (BAM) procedures. MacConkey II agar with sorbitol (BBL, Becton, Dickinson and Company, Sparks, MD, USA), a selective and differential media for the detection of sorbitol-non-fermenting E. coli O157: H7, was used for enumerating the cells. When plated on MacConkey II agar with sorbitol, two different types of colonies were observed. The E.coli O157: H7 produced colorless colonies and the generic E. coli formed sorbitol positive pink colonies. We counted both types of colonies separately to understand the types of E.coli inactivation in the composting experiment. To enumerate the 
colonies, cotton media, and blended feedstock samples were serially diluted in phosphate buffer solution (PBS), and subsequently blended samples were plated in MacConkey II agar plates. After plating, petri dishes were incubated at $37^{\circ} \mathrm{C}$ for $24 \mathrm{~h}$ and the colonies were enumerated.

\subsection{Temperature Monitoring, Sample Collection, and Analysis}

Temperatures from the 14 bins were monitored everyday using a handheld thermometer for approximately 45 days. The cotton balls were collected routinely till 35 days of composting after the beginning of the experiment. In addition to cotton balls, we also collected feedstock material for the testing of $E$. coli levels. Collected cotton balls were analyzed for E.coli O157: H7 and generic E. coli concentrations over the experimental period. The cotton balls were initially weighed and diluted to 10 times with PBS and then serially diluted as needed. The initial concentrations of E. coli and E.coli O157: H7 were enumerated in both feedstock and cotton media. In addition to the bacteria, the moisture content (MC), total carbon content (TC), and total nitrogen (TN) content were analyzed using standard protocols (APHA, 1998). The MC was determined by drying the feedstock samples at $105^{\circ} \mathrm{C}$ for 24 hours, the TC content was measured by placing the dried feedstock sample at $550^{\circ} \mathrm{C}$ for 1 hour, and TN concentration was analyzed using TNT Persulfate Digestion Method (method \#10071).

To determine the impact of compost pile height on E. coli survival, the feedstock and cotton balls were collected from each column at different depths on day $0,20,35$, and 45 . To represent the first column (C1) $10 \mathrm{~cm}$ below the simulated pile surface, samples were collected from depth $d_{1}, d_{2}, d_{3}, d_{4}$, and $d_{5}$. The Same process was followed to analyze samples of each depth from every column. All the samples were analyzed within 24 hours of collection.

\section{Results}

\subsection{Temperature Profiles}

The temperature profiles of column (pile) 1 and column (pile) 2 are shown in Figure 2. The temperature profiles of column (pile) 3 and column (pile) 4 are shown in Figure 3. The heights of piles 1 and 2 were $100 \mathrm{~cm}$ and 80 $\mathrm{cm}$, respectively, while pile 3 and 4 heights were $60 \mathrm{~cm}$ and $40 \mathrm{~cm}$, respectively. In pile 1, maximum temperature varied from 48.3 to $56.1{ }^{\circ} \mathrm{C}$ (over 36 day period). In piles 2,3 , and 4 , the maximum temperature varied $46.3-51.5^{\circ} \mathrm{C}, 49-49.5^{\circ} \mathrm{C}$, and $44-47.5^{\circ} \mathrm{C}$, respectively. 

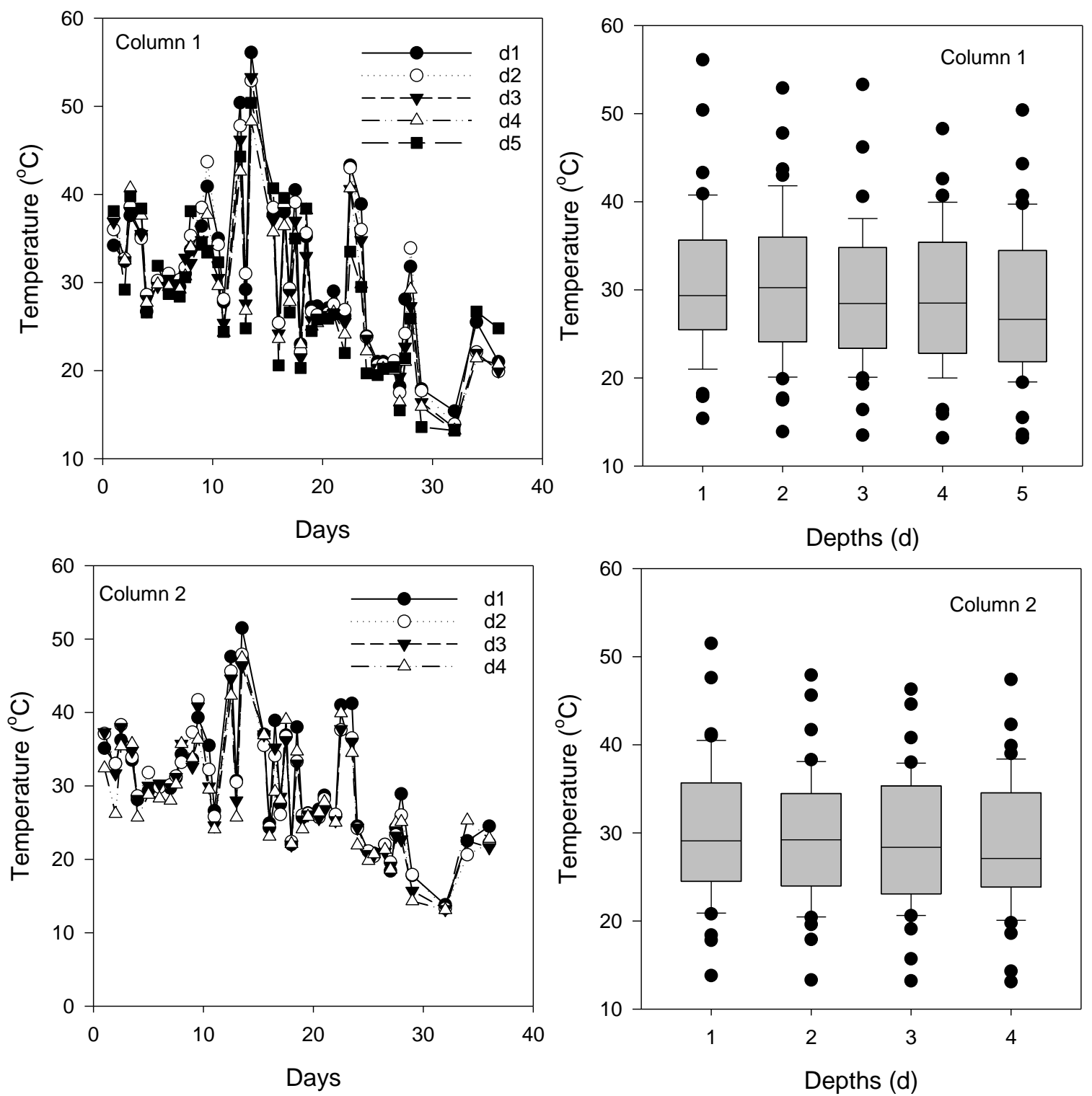

Figure 2. Temperature profile in column (pile) 1 and column (pile) 2. Temperature changes over the time are shown in left, and corresponding box plot analyses for various depths are shown on right

The maximum temperature in pile 1 was highest compared to the maximum temperatures of other piles. The highest maximum temperature of $56.1^{\circ} \mathrm{C}$ was obtained at $\mathrm{d}_{1}(10 \mathrm{~cm}$ below from the top of the pile), while the lowest maximum temperature of $48.3^{\circ} \mathrm{C}$ was obtained at $\mathrm{d}_{4}(70 \mathrm{~cm}$ below from the top of the pile) (Figure 1). The minimum temperature at $\mathrm{d}_{1}\left(15.4^{\circ} \mathrm{C}\right)$ was slightly higher than that at $\mathrm{d}_{2}\left(13.9^{\circ} \mathrm{C}\right), \mathrm{d}_{3}\left(13.5^{\circ} \mathrm{C}\right), \mathrm{d}_{4}\left(13.2^{\circ} \mathrm{C}\right)$, and $\mathrm{d}_{5}\left(13.2{ }^{\circ} \mathrm{C}\right)$. In pile 1 , the temperature greater than $55^{\circ} \mathrm{C}$ was found for two days at $\mathrm{d}_{1}$, while at $\mathrm{d}_{2}, \mathrm{~d}_{3}$, and $\mathrm{d}_{5}$ it was only for one day. 

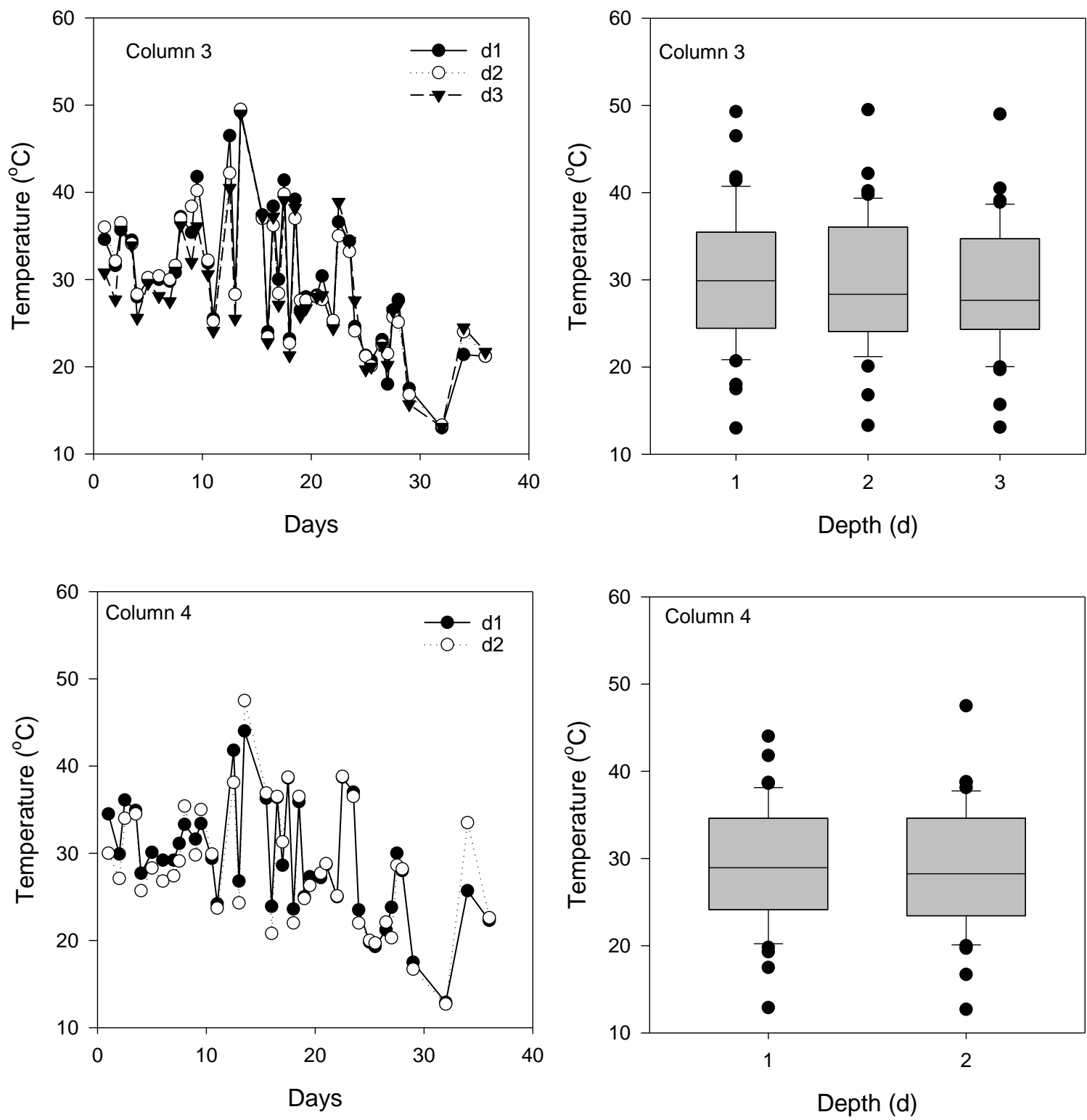

Figure 3. Temperature profile of column (pile) 3 and column (pile) 4. Temperature changes over the time are shown in left, and corresponding box plot analyses for various depths are shown on right

In pile 2, the temperature greater than $50{ }^{\circ} \mathrm{C}$ was obtained only once at $\mathrm{d}_{1}$. The temperature of piles 3 and 4 was below $50{ }^{\circ} \mathrm{C}$. In pile 1 , temperature greater than $40^{\circ} \mathrm{C}$ was obtained for 5 days, while in pile 2, pile 3 , and pile 4 , the temperature greater than $40{ }^{\circ} \mathrm{C}$ was found only for 4,4 , and 2 days, respectively. In piles 1 and 2 , the temperature greater than $30^{\circ} \mathrm{C}$ was for 20 and 18 days, while in piles 3 and 4 , it was for 21 and 17 days, respectively. In general, upper portions of the piles showed a higher temperature than lower portions of the temperature. While the average temperature (over 36 day period) among piles was relatively similar (29.4 \pm $0.7^{\circ} \mathrm{C}$ ), the difference between the maximum and minimum temperatures was higher for piles 1 and 2 compared to piles 3 and 4 . In this study, the temperature of each pile was relatively higher during the initial phase, however, the temperature reached below $40{ }^{\circ} \mathrm{C}$ over the time. This lower temperature could be due to the decrease in ambient air temperature (Figure 1). Another potential reason could be the aging of the compost pile. Studies showed that the temperature of compost file reduces over the time, particularly after 2-3 weeks. 


\subsection{Changes in E. coli Concentrations}

The changes in generic E.coli and E.coli 0157: H7 concentrations with the time in the cotton media in four different piles are presented in Figures 4 and 5. Initial generic E. coli concentrations of cotton media were in seven orders of magnitude. On day 20, the $E$. coli level in pile 1 was reduced to approximately four orders of magnitude, while in piles 2, 3, and 4, E. coli levels were reduced to five orders of magnitude. The lowest $E$. coli level in pile 1 was at $d_{1}$, which is consistent with a higher temperature at this depth. On day 35 , however, an increase in E. coli levels in cotton media was observed in each pile, which was unexpected. This regrowth could be attributed to decreased temperature. After day 20, the ambient air temperature was reduced, and a cumulative $30 \mathrm{~mm}$ of precipitation was observed between day 20 and 35, which resulted in increased moisture content of each column. Similar to E. coli generic, E.coli 0157:H7 levels were reduced from seven orders of magnitude to four orders of magnitude in pile 1, and in pile 2, 3, and 4 it was reduced from seven orders of magnitude to five orders of magnitude.
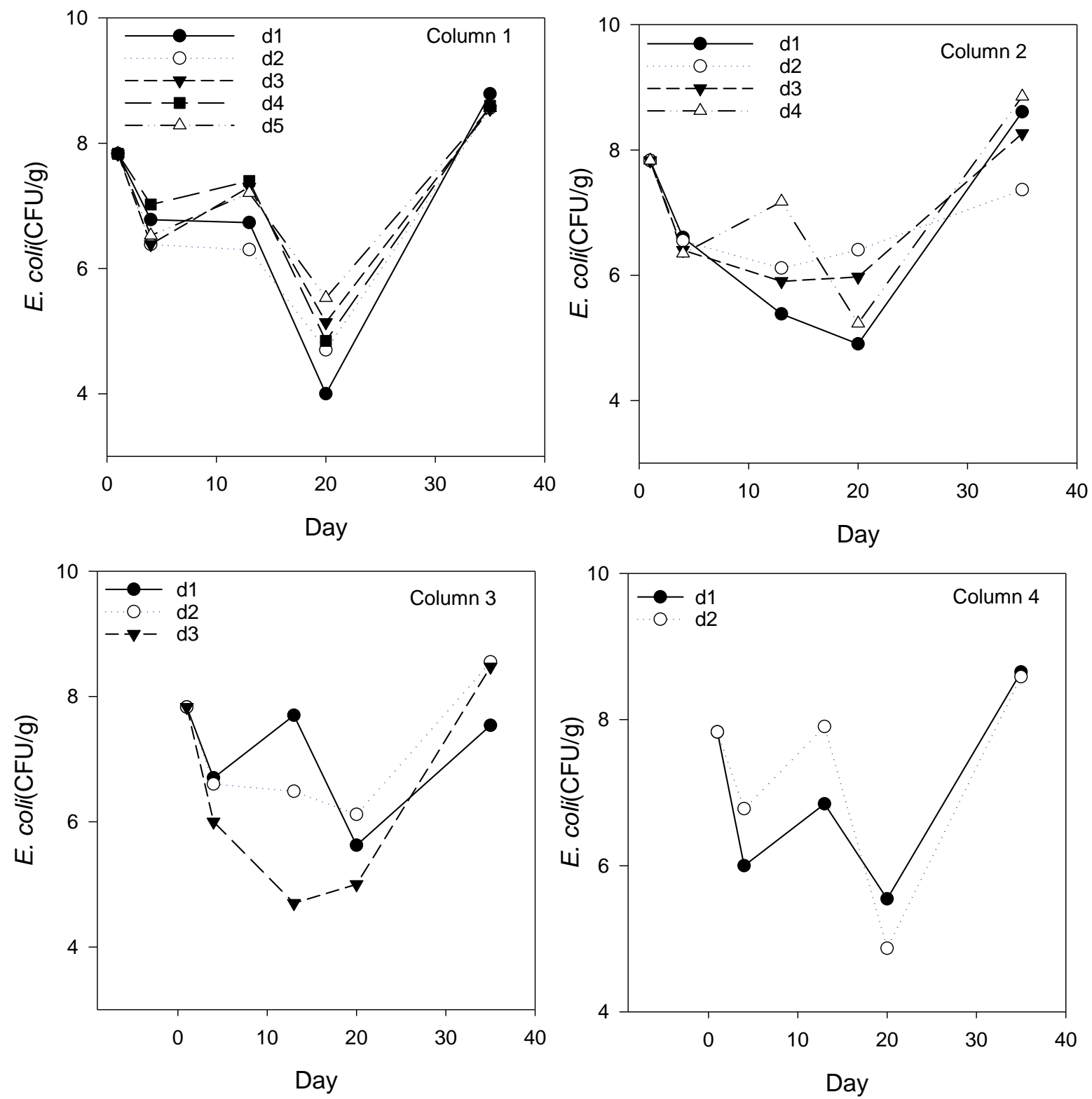

Figure 4. Survival patterns of $E$. coli in inoculated cotton media at various depths (columns 1- 4 are representatives of piles 1-4) 

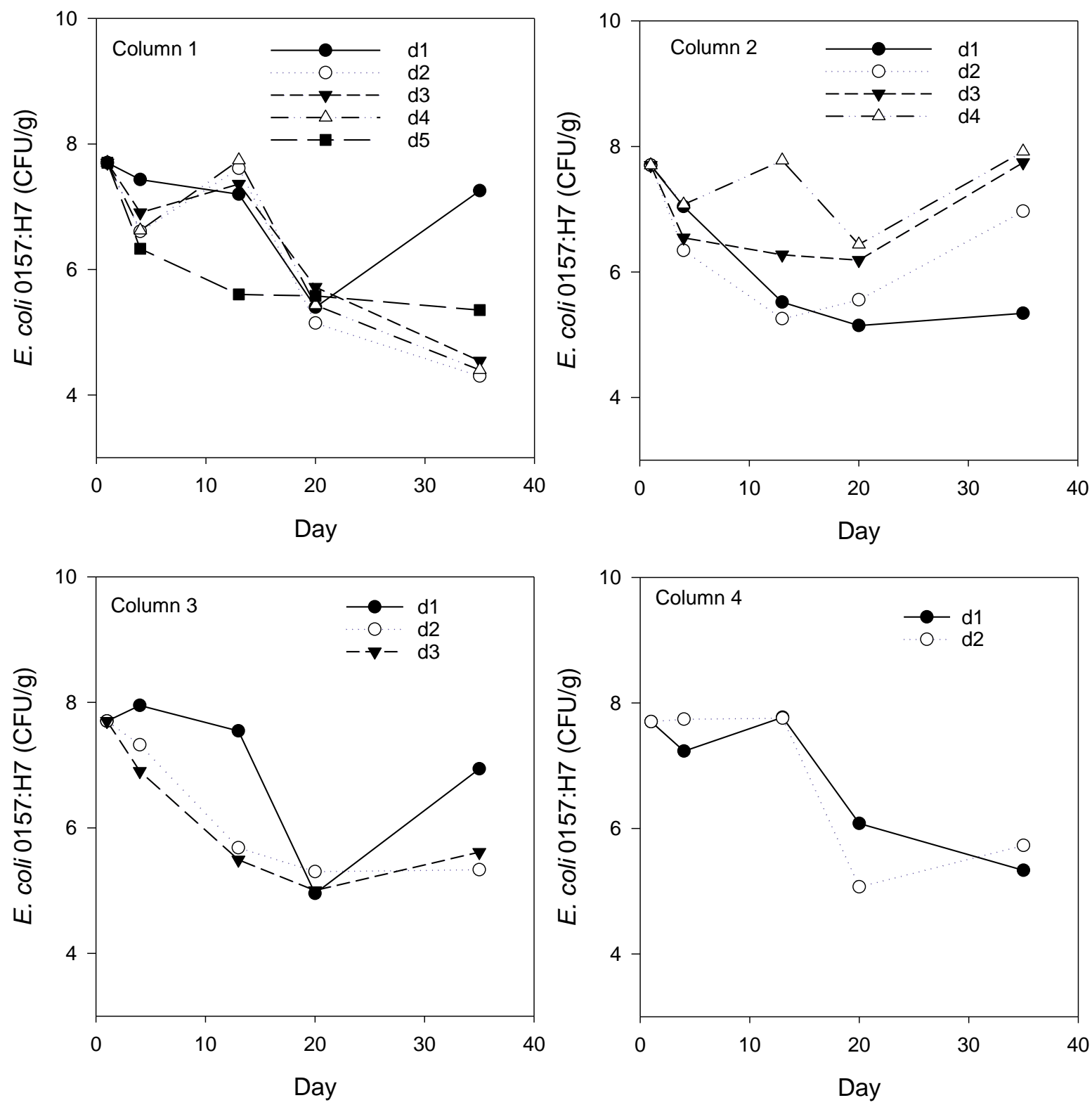

Figure 5. Survival patterns of $E$. coli $\mathrm{O} 157: \mathrm{H} 7$ in inoculated cotton media at various depths (columns 1- 4 are representatives of piles 1-4)

The changes in E. coli levels in compost material are shown in Figure 6. Initial E. coli and E. coli 0157: H7 levels were in seven orders of magnitude. Compared to cotton media, the reduction in $E$. coli levels in compost was relatively slower. As an example, on day 20,E. coli levels in cotton media were four and five orders of magnitude, while in compost material E. coli levels were in seven and eight orders of magnitude. The regrowth of $E$. coli, which was noticeable in cotton media on day 35, it was not observed in compost material. On day 47, both $E$. coli and E. coli $\mathrm{O} 157$ : $\mathrm{H} 7$ levels in compost material varied from four to seven orders of magnitude. The average of E. coli O157: $\mathrm{H} 7$ and $E$. coli levels among $\mathrm{d}_{1}, \mathrm{~d}_{2}, \mathrm{~d}_{3}$, and $\mathrm{d}_{4}$ were $4.9( \pm 0.7)$ and $5.6( \pm 0.7)$, respectively. 

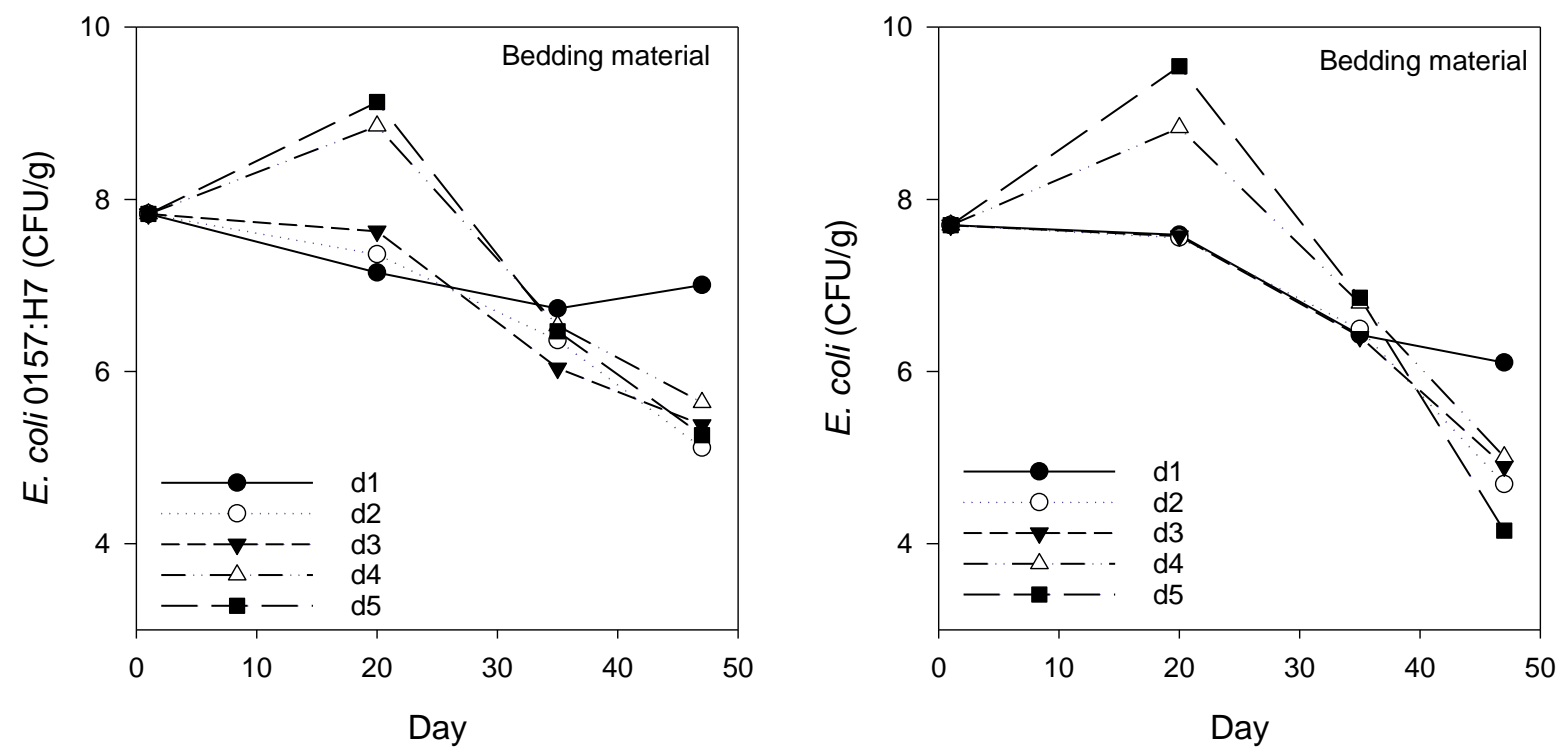

Figure 6. Survival patterns of $E$. coli $\mathrm{O} 157: \mathrm{H} 7$, and generic $E$. coli in bedding material (i.e., compost feedstock)

\subsection{Changes in Moisture, Total Carbon, and Total Nitrogen}

Table 1 shows the MC, TC, and TN of initial and final samples of compost. Results indicated that MC, TC, and TN may change with depths of piles. At top surface (i.e., $d_{1}$ ), the moisture of compost changed from $59.6 \%$ to $43.6 \%$, while at lower portion of compost pile (i.e., $\mathrm{d}_{5}$ ) moisture was increased from $59.6 \%$ to $52.3 \%$. This could be attributed to both water losses as evaporation from the upper surface of the compost pile, and seepage of moisture from the top surface to bottom. The change in carbon content of compost, however, was opposite to moisture content. In top surface, TC changed from 21.4 to $29.2 \%$, while in the lower portion of column TC was reduced from 21.4 to $19.1 \%$. In addition to MC and TC, the impact of column depth on TN was observable. For example, at the upper portion of pile $\left(\mathrm{d}_{1}\right)$, the reduction in nitrogen of feedstock was $6 \%$, while in the lower portion of pile $\left(\mathrm{d}_{5}\right)$, the reduction was approximately $60 \%$.

Table 1. Descriptive summary of nutrient characterizes of compost feedstock

\begin{tabular}{ccccccc}
\hline \multirow{2}{*}{ Depth } & \multicolumn{2}{c}{ MC $(\%)$} & \multicolumn{2}{c}{ TC $(\%)$} & \multicolumn{2}{c}{ TN $(\mathrm{mg} / \mathrm{L})$} \\
\cline { 2 - 7 } & Initial & Final & Initial & Final & Initial & Final \\
\hline 1 & 59.6 & 43.6 & 21.4 & 29.2 & 700 & 657 \\
2 & 59.6 & 66.9 & 21.4 & 16.3 & 700 & 529 \\
3 & 59.6 & 65.4 & 21.4 & 17.5 & 700 & 230 \\
4 & 59.6 & 66.3 & 21.4 & 16.9 & 700 & 315 \\
5 & 59.6 & 62.3 & 21.4 & 19.1 & 700 & 273 \\
\hline
\end{tabular}

\section{Discussion}

In an ideal scenario, the temperature of compost pile reaches more than $65{ }^{\circ} \mathrm{C}$ for multiple days, however, the challenges in reaching ideal temperature $\left(>65^{\circ} \mathrm{C}\right)$ is well reported (Copperband, 2002; Haug, 1993; Wichuk \& McCartney, 2007). Previous studies showed the survival of pathogens in composting when the temperature was below $60{ }^{\circ} \mathrm{C}$ (Erickson, Liao, Ma, Jiang, \& Doyle, 2009a,b). Shephard et al. (2007) conducted a composting study and observed a difference in concentrations from the Day 1-7 of composting between the surface and bottom of the compost pile. The concentrations reached to undetected level afterward during their summer trail. However, the inactivation was not significant during the winter trail. The difference in the E. coli concentrations was noticed among samples from base and surface of the piles.

Erickson et al. (2009a, b) determined the fate of pathogens in surface and sub-surface sites near the base of static compost piles of chicken litter and peanut hulls and reported the presence of E. coli $O 157$ on the surface of the pile. However, pathogens were not detected in sub-surface samples. These results are similar to this experiment while comparing the changes in generic E. coli. E. coli was detected on the surface as well as subsurface samples. The study also found that during summer the subsurface temperature was consistently greater than $45^{\circ} \mathrm{C}$. In 
general, the subsurface temperature was always higher than surface temperature (from $8{ }^{\circ} \mathrm{C}$ to $16{ }^{\circ} \mathrm{C}$ ). While conducting the experiment in fall, the temperature difference between the surface and subsurface was relatively higher (varies from $23{ }^{\circ} \mathrm{C}$ to $35^{\circ} \mathrm{C}$ ).

Both cotton balls and compost material showed that the composting period of 35-47 days was insufficient to reduce E. coli levels to more than three orders of magnitude. Various general guidelines established by various regulatory agencies are in place to ensure the compost microbial quality and safety. For example, according to UK compost quality criteria, the $E$. coli levels in the composted material should be lower than three orders of magnitude (i.e., $1000 \mathrm{CFU} / \mathrm{g}$ ). Similarly, the USEPA recommends E. coli levels lower than three orders of magnitude in compost material. In a standard condition, compost material should reach a temperature greater than $60{ }^{\circ} \mathrm{C}$ for 3 days continuously. In the current study, however, the temperature of compost did not reach 60 ${ }^{0} \mathrm{C}$, potentially due to smaller size of piles and lower ambient temperature.

The factors such as feedstock type, carbon to nitrogen ratio, weather conditions, and mixing of the compost piles influence the temperature of compost piles and the quality of compost (Erickson et al., 2015; Sakthivadivu, Sivakumar, Kumar, \& Natarajan, 2015; Yang et al., 2015). While composting swine manure with rice straw, Zhu (2007) observed that it took $5.1 \mathrm{hr}$ and $3.6 \mathrm{hr}$ to reach the bin temperature of $55^{\circ} \mathrm{C}$, when the $\mathrm{C}: \mathrm{N}$ ratios were 20 and 25 , respectively. The authors also found that the thermophilic temperature $\left(>50{ }^{\circ} \mathrm{C}\right)$ remained $306 \mathrm{hr}$ at $20 \mathrm{C}$ : $\mathrm{N}$ ratio and $286 \mathrm{hr}$ for $25 \mathrm{C}$ : $\mathrm{N}$ ratio. Further, occasional mixing (weekly and bi-weekly) are reported to elevate temperature of compost piles (Michel et al., 1996; Ogunwande, Osunade, Adekalu, \& Ogunjimi, 2008). Rasapoor, Nasrabadi, Kamali, \& Hoveidi (2009) observed that the thermophilic phase lasted 13, 9, and 4 weeks for the aeration rates of $0.4,0.6$, and $0.9 \mathrm{~L} / \mathrm{min} / \mathrm{kg}$, respectively during the composting of municipal solid waste, indicating the effects of aeration on temperature.

These preliminary results showed that certain parameters such as moisture content, total carbon, and nitrogen of compost may vary with the pile depths. The height of the pile is shown to be influential in affecting the temperature of the pile, and hence pathogen inactivation. Because of lower temperature in the later phase of the experiment, this study can be considered as sub temperature composting study. Results may not be directly applicable to a compost pile, which consistently maintains a temperature higher than $60{ }^{\circ} \mathrm{C}$ for an extended period. Pathogen inactivation can be relatively faster in full-scale composting facility, where the temperature of the pile often reaches to $60{ }^{\circ} \mathrm{C}$. Nevertheless, the findings of this study provided insights how the depth and height of compost pile may influence temperature, pathogen level, moisture content, carbon and total nitrogen of compost.

The turning of the pile is a suggested method for increasing the temperature of compost pile (Senne et al., 1994), which was applied in this study. However, the temperature change after turning was not considerable mainly due to the smaller size of piles. Fernandes et al. (1994) showed that the average peak temperature at the top, middle and bottom sections of compost piles were within the range of $59-72^{\circ} \mathrm{C}, 61-72^{\circ} \mathrm{C}$, and $56-57^{\circ} \mathrm{C}$, respectively. This study showed that latitudinal temperature change may occur. However, those changes depend on the pile height and depths of monitoring point. The pattern of temperature profiles over the composting period was similar among all the composting depths.

As the temperature of each column among the depths was relatively similar, the inactivation of $E$. coli did not differ considerably from one depth to another. These results signify that the inactivation of the pathogen in a compost pile could be uniform, if the temperature is consistent, and uniformity of compost pile is maintained with frequent mixing. The study showed that the height of pile influences the compost temperature. In general, the compost temperature in smaller piles was lower than that of the larger pile.

\section{Conclusions}

Here we studied the changes in temperature during composting process. Further, pathogen inactivation in compost piles was evaluated. In the lab-scale experiment, we simulated the conditions of compost piles of different depths. Changes in generic E. coli and E. coli O157: H7 levels were observed for more than month. In each pile, we collected 5 (near center) to 2 (at the edge) samples during each sampling event. During the experiment, peak temperature $\left(>50{ }^{\circ} \mathrm{C}\right)$ was reached after two weeks of composting. The temperature of the piles fluctuated considerably over the time. The decreasing trends in the concentrations of pathogens in cotton balls, which were placed in the center of the pile, indicated that composting process has a potential to reduce pathogens under certain conditions particularly if the pile achieved lethal temperature range. We anticipate that these lab-scale data provides additional insights in terms of pathogen inactivation and associated uncertainty during composting process. 


\section{Acknowledgments}

The authors thank the Division of Agriculture and Natural Resources, Veterinary Medicine School Extension, and University of California Cooperative Extension (UCCE) for supporting this work.

\section{References}

Ahmed, A. U., \& Sorensen, D. L. (1995). Kinetics of pathogen destruction during storage of dewatered biosolids. Water Environment Research, 67(2), 143-150. https://doi.org/10.2175/106143095X131286

American Public Health Association (APHA). (1998) Standard methods for the examination of water and wastewater. A.W.W.A., Water Environment Federation (WEF). United Book Press, Inc., Baltimore, Maryland, USA.

Biswas, S., Pandey, P. K., \& Farver, T. B. (2016). Assessing the impacts of temperature and storage on Escherichia coli, Salmonella, and L. monocytogenes decay in dairy manure. Bioprocess and Biosystems Engineering, 39(6), 901-913. https://doi.org/10.1007/s00449-016-1569-x

Blake, J. P., \& Donald, J. O. (1992). Alternatives for the disposal of poultry carcasses. Poultry Science, 71, 1130-1135. https://doi.org/10.3382/ps.0711130

Cole, K. J. (2015). Bacterial counts in composted and fresh recycled dairy manure bedding. The Ohio State University.

Copperband, L. (2002). The art and science of composting- A resources for farmers and compost producers. University of Wisconsin- Madison, Center for Integrated Agricultural Systems.

Erickson, M. C., Liao, J., Ma, L., Jiang, X., \& Doyle, M. P. (2009a). Pathogen inactivation in cow manure compost. Compost Science and Utilization, 17(4), 229-236. https://doi.org/10.1080/1065657X.2009.10702428

Erickson, M. C., Liao, J., Ma, L., Jiang, X., \& Doyle, M. P. (2009b). Inactivation of Salmonella spp. in cow manure composts formulated to different initial C: N ratios. Bioresource Technology, 100(23), 5898-5903. https://doi.org/10.1016/j.biortech.2009.06.083

Erickson, M. C., Liao, J., Jiang, X., \& Doyle, M. P. (2014). Inactivation of pathogens during aerobic composting of fresh and aged dairy manure and different carbon amendments. Journal of Food Protection, 77(11), 1911-1918. https://doi.org/10.4315/0362-028X.JFP-14-194

Erickson, M. C., Smith, C., Jiang, X., Flitcroft, I. D., \& Doyle, M. P. (2015). Manure source and age affect survival of zoonotic pathogens during aerobic composting at sublethal temperatures. Journal of Food Protection, 78(2), 302-310. https://doi.org/10.4315/0362-028X.JFP-14-288

Fernandes, L., Zhan, W., Patni, N. K., \& Jui, P. Y. (1994). Temperature distribution and variation in passively aerated static compost piles. Bioresource Technology, 48(3), 257-263. https://doi.org/10.1016/0960-8524(94)90155-4

Grewal, S. K., Rajeev, S., Sreevatsan, S., \& Michel, F. C. (2006). Persistence of Mycobacterium avium subsp. paratuberculosis and other zoonotic pathogens during simulated composting, manure packing, and liquid storage of dairy manure. Applied and Environmental Microbiology, 72, 565-574. https://doi.org/10.1128/AEM.72.1.565-574.2006

Haug, R. T. (1993). Chapter 5: Kinetics of Heat Inactivation. In The practical handbook of compost engineering. Lewis Publishers, Boca Raton, FL, USA.

Jiang, X., Morgan, J., \& Doyle, M. P. (2003). Fate of Escherichia coli O157: H7 during composting of bovine manure in a laboratory-scale bioreactor. Journal of Food Protection, 66(1), 25-30. https://doi.org/10.4315/0362-028X-66.1.25

Luo, W., Chen, T. B., Zheng, G. D., Gao, D., Zhang, Y. A., \& Gao, W. (2008). Effect of moisture adjustments on vertical temperature distribution during forced-aeration static-pile composting of sewage sludge. Resource, Conservation and Recycling, 52(4), 635-642. https://doi.org/10.1016/j.resconrec.2007.08.004

Michel, F. C., Forney, L. J., Huang, A. J. F., Drew, S., Czuprenski, M., Lindeberg, J. D., \& Reddy, C. A. (1996). Effects of turning frequency, leaves to grass mix ratio and windrow vs. pile configuration on the composting of yard trimmings. Compost Science \& Utilization, 4(1), 26-43.

https://doi.org/10.1080/1065657X.1996.10701816

Ogunwande, G. A., Osunade, J. A., Adekalu, K. O., \& Ogunjimi, L. A. O. (2008). Nitrogen loss in chicken litter 
compost as affected by carbon to nitrogen ratio and turning frequency. Bioresource Technology, 99(16), 7495-7503. https://doi.org/10.1016/j.biortech.2008.02.020

Pandey, P. K., Biswas, S., Vaddella, V. K., \& Soupir, M. L. (2015). Escherichia coli persistence kinetics in dairy manure at moderate, mesophilic, and thermophilic temperatures under aerobic and anaerobic environments. Bioprocess and Biosystems Engineering, 38(3), 457-467. https://doi.org/10.1007/s00449-014-1285-3

Pandey, P. K., Cao, W., Wang, Y., \& Vaddella, V. (2016). Predicting Salmonella Typhimurium reductions in poultry ground carcasses. Poultry Science, 95(11), 2640-2646. https://doi.org/10.3382/ps/pew242

Rasapoor, M., Nasrabadi, T., Kamali, M., \& Hoveidi, H. (2009). The effects of aeration rate on generated compost quality, using aerated static pile method. Waste Management, 29(2), 570-573. https://doi.org/10.1016/j.wasman.2008.04.012

Sakthivadivu, R., Sivakumar, K., Kumar, V. R. S., \& Natarajan, A. (2015). Chemical changes during composting of poultry waste with coirpith waste and sugarcane top. International Journal of Science, Environment and Technology, 4(1), 40-49.

Sartaj, M., Fernandes, L., \& Patni, N. K. (1997). Performance of forced, passive, and natural aeration methods for composting manure slurries. Transactions of the ASAE, 40(2), 457-463. https://doi.org/10.13031/2013.21273

Senne, D. A., Panigrahy, B., \& Morgan, R. L. (1994). Effect of composting poultry carcasses on survival of exotic avian viruses: highly pathogenic avian influenza (HPAI) virus and adenovirus of egg drop syndrome-76. Avian Diseases, 38(4), 733-737. https://doi.org/10.2307/1592108

Shepherd, M. W., Liang, P., Jiang, X., Doyle, M. P., \& Erickson, M. C. (2007). Fate of Escherichia coli O157: H7 during on-farm dairy manure-based composting. Journal of Food Protection, 70(12), 2708-2716. https://doi.org/10.4315/0362-028X-70.12.2708

Stanford, K., Reuter, T., Gilroyed, B. H., \& McAllister, T. A. (2015). Impacts of sporulation temperature, exposure to compost matrix and temperature on survival of Bacillus cereus spores during livestock mortality composting. Journal of Applied Microbiology, 118, 989-997. https://doi.org/10.1111/jam.12749

Toth, J. D., Aceto, H. W., Rankin, S. C., \& Dou, Z. (2011). Survival characteristics of Salmonella enterica serovar Newport in the dairy farm environment. Journal of Dairy Science, 94(10), 5238-5246. https://doi.org/10.3168/jds.2011-4493

Turner, C. (2002). The thermal inactivation of E. coli in straw and pig manure. Bioresource Technology, 84(1), 57-61. https://doi.org/10.1016/S0960-8524(02)00008-1

Vaddella, V. K., Pitesky, M., Wenlong, C., Govinthasamy, V., Shi, J., \& Pandey, P. K. (2016). Assessing Salmonella typhimurium persistence in poultry carcasses under multiple thermal conditions consistent with composting and wet rendering. Poultry Science, 95(3), 705-714. https://doi.org/10.3382/ps/pev373

Wichuk, K. M., \& McCartney, D. (2007). A review of the effectiveness of current time-temperature regulations on pathogen inactivation during composting. Journal of Environmental Engineering and Science, 6(5), 573-586. https://doi.org/10.1139/S07-011

Yang, S., Hou, L., Zhai, Y., \& Zhang, C. (2015). Effects of bacteria and accessories on chicken manure compost. Agricultural Science \& Technology, 16(2), 317-321.

Zhou, C., Liu, Z., Huang, Z. L., Dong, M., Yu, X. L., \& Ning, P. (2015). A new strategy for co-composting dairy manure with rice straw: Addition of different inocula at three stages of composting. Waste Management, 40 , 38-43. https://doi.org/10.1016/j.wasman.2015.03.016

Zhu, N. (2007). Effect of low initial $\mathrm{C} / \mathrm{N}$ ratio on aerobic composting of swine manure with rice straw. Bioresource Technology, 98(1), 9-13. https://doi.org/10.1016/j.biortech.2005.12.003

Zhu, F. X., Wang, W. P., Hong, C. L., Feng, M. G., Xue, Z. Y., Chen, X. Y., Yao, Y. L., \& Yu, M. (2012). Rapid production of maggots as feed supplement and organic fertilizer by the two-stage composting of pig manure. Bioresource Technology, 116, 485-491. https://doi.org/10.1016/j.biortech.2012.04.008

\section{Copyrights}

Copyright for this article is retained by the author(s), with first publication rights granted to the journal.

This is an open-access article distributed under the terms and conditions of the Creative Commons Attribution license (http://creativecommons.org/licenses/by/4.0/). 